\title{
眼球運動解析によるヒューマンエラー防止のための危険予知
}

\author{
古莊 雅生 ${ }^{*}$ 平井 貴裕 ${ }^{*}$ 櫻井 美奈***
}

\section{Foresight of Incidental and Dangerous Situation for Preventing Human Errors by Using Analysis of Eye Movement}

\author{
Masao FURUSHO, Takahiro HIRAI and Mina SAKURAI
}

\begin{abstract}
It is very important to make foresight of the incidental and dangerous situation for preventing human errors. It is pointed out that almost causes of marine disasters are human errors. Authors propose the foresight training for preventing human errors by using the sample sheets including dangerous situations of vehicle transportation. In the industrial production field and the road traffic situation, excepting the marine traffic situation, the effect of the foresight training has been already confirmed. Especially in the marine traffic situation, the effectiveness of the foresight training is not confirmed yet.

This research by using eye-movement analyzer("Free-View") shows the characteristics of the foresight process relating to the human errors by using sample sheets including the incidental dangerous situations of the road traffic and the small boat.

Based on the experimental measurements, the results are as follows;

(1) There is a strong relationship between the characteristics of eye movement and the foresight ability of the incidental and dangerous situation, in case of judgement for the traffic situation.

(2) The evaluation of foresight ability is strongly influenced by the static characteristics of eye movement of the average gazing position more than by the dynamic characteristics of the sight-line displacement.
\end{abstract}

\section{1.はじめに}

自動車交通や生産工場の作業場面では、災害や事 故を防止するために危険予知という手法を取り入 れ、その効果が報告されている(1)。しかし、船舶交通 や海上労㗢における危険予知活動の導入が呼びかけ られているものの、それを評価した報告はなく、よ り有効な危険予知活動の手法を導入することが必要 である。さらに、災害原因がヒューマンファクター によるものとの指摘も多く、災害防止の観点から効 果的な手法を開発する必要がある。

そこで、既に従来から用いられている日本自動車
連盟（以下“JAF”）が発行している道路交通場面の 危険予知シートと、神戸商船大学が作製したプレ ジャーボート版危険予知シートを提示しながら、非 接触眼球運動測定装置（以下 “Free-View”）を用い た実験を行い、危険予知シート（静止画）から得ら れる視覚情報を認識する際の一般的な視覚特性や、 危険な状況を認識する際の眼球運動特性を通じて危 険予知活動の手法と評価に関する知見を得たので報 告する。

\section{2. 危険予知}

海上交通システムの構成要素は、その安全管理手

* 正 会 員 神戸商船大学（T658-0022 神戸市東灘区深江南町5-1-1)

** 学生会員 神戸商船大学大学院（干658-0022 神戸市東灘区深江南町5-1-1）

*** 学生会員 慶應義塾大学大学院（干252-8520 藤沢市遠藤5322） 


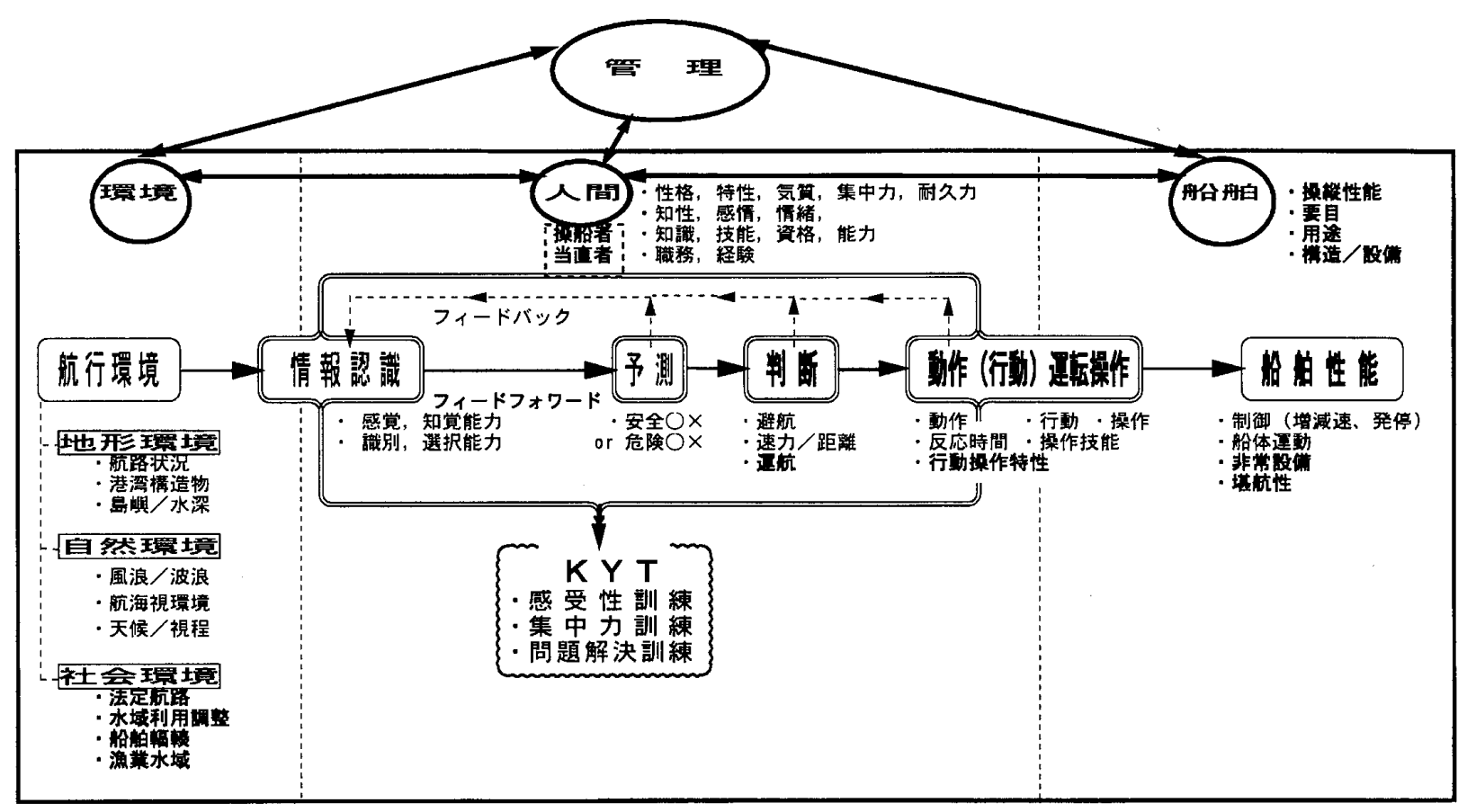

図 1 危険予知訓練（KYT）の位置づけ

法を検討するとき、1.Man(人間)、2. Machine(船 舶)、3. Media (環境)、4. Management（管理） という $4 \mathrm{M}$ の要素に分けられる。危険予知は、これ らの構成要素のうち、“Man”の要素（ヒューマン ファクター）に焦点を向けたヒューマンエラー予防 策の一つである。

筆者らが考案したこれらの構成要素と危険予知と の関係モデルを図1に示す。そのモデルではシステ 厶管理者としての人間は、航行環境にある様々な情 報という刺激を受けながら、予測、判断、操作とい うフィードフォワードとフィードバックのループ的 な繰り返しのプロセスを経て、人間行動の目的達成 に向けた行動を実行すると捉えている。危険予知と は、このようなループ的プロセスを含む人間行動の 目的を達成するための行動改善手法であり、1. 危険 な状況に対する感受性を高女、2．危険な状況に適応 する集中力を涵養し、3．危険な状況を脱するための 問題解決能力を高めるという意義を持つものと位置 付けられる。

危険予知とは、ある状況の場面を見た時に、そこ に潜んでいる危険を認識する感性、すなわち危険感 受性を高めるために考案された手法である。その手 法は文章やイラストを用いる方法、あるいはビデオ 映像を用いる手法など様々な方法が考案されてい る。

危険子知の効果は、危険感受性テスト、小集団討 議、カウンセリングを組み合わせた危険予測に関す

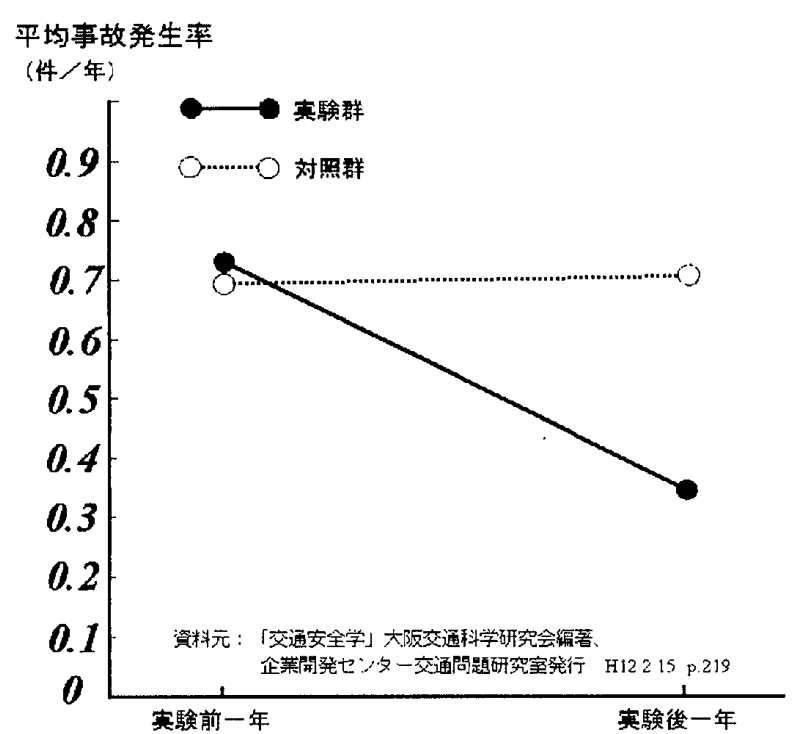

図 2 事故発生率の変化（深沢、1990）

る安全教育プログラムの実施を通じて、その訓練効 果に関する調查研究として、1990年、深沢により報 告されている(2)。その危険感受性テストは、樑沢自身 が独自に開発したイラスト方式によるもので、2 枚 の連続した運転場面のそれぞれに危険な状況を含ん だイラストが提示されたものであった。図 2 は、こ の安全プログラムに参加したタクシードライバー群 (実験群)と参加していないドライバー群 (対照群) を比較し、プログラム実施前後 1 年間のそれぞれの 平均事故発生率を検討したものである。実験群の事 故発生率は対照群と比較すると大幅に減少し、危険 予知の効果を示している。 


\section{3. 実 験}

\section{1 実験概要}

実験は、屋外昼光の影響を防ぎ測定環境を一定に 保つため、暗幕をかけて天井灯を点灯させた実験室 で行った。被験者は、ディスプレイから970 mm離れ た位置にある顎台に頭部を乗せ、顔面の位置が動か ない姿勢で座り、ディスプレイに提示された危険子 知シートを1枚ずつ観察し、そのシート上部に記載 されている設問内容に口頭で回答した。危険予知 シートの一例を図 3 、図 4 に示す。実験者は、その 回答を記録しながら合計15枚の危険予知シートを ディスプレイに提示した。

実験は一人ずつ行い、ディスプレイに危険予知 シートが提示された時点を計測開始時とし、被験者 の回答終了後に実験者が「他にもありますか」と尋 ね、被験者が「ありません」と回答した時点を計測 終了時とした。実験開始からそれぞれの提示シート に要する較正や、15枚のシートに回答する時間を含 めた実験終了までの所要時間は約30分であった。

較正は、5 点較正法を用いて測定前に行った。さ らに、それぞれの危険予知シート間に挿入した微調 整用画面を用いて視線と視対象にずれがないことを

・ あなたは約東の時間に㜊れていたためイライラしながら信昂が变わ るのを待ってい末した。写真はちようど信号が青に変わったところで す。右には直倠し上うとしているワンボックス車加あり步道には女 性三人が立方話古しています。急いで

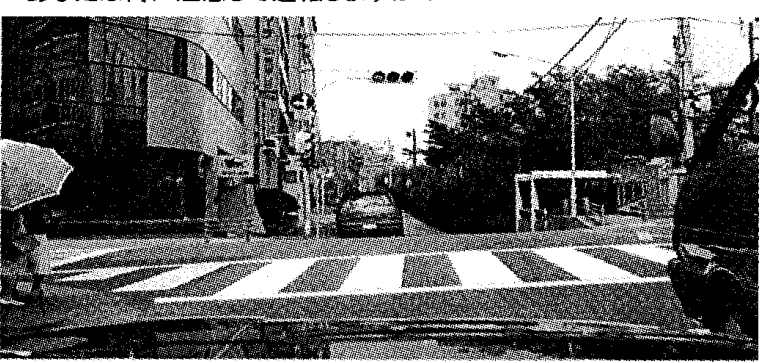

図 3 危険予知シート シートNo.1

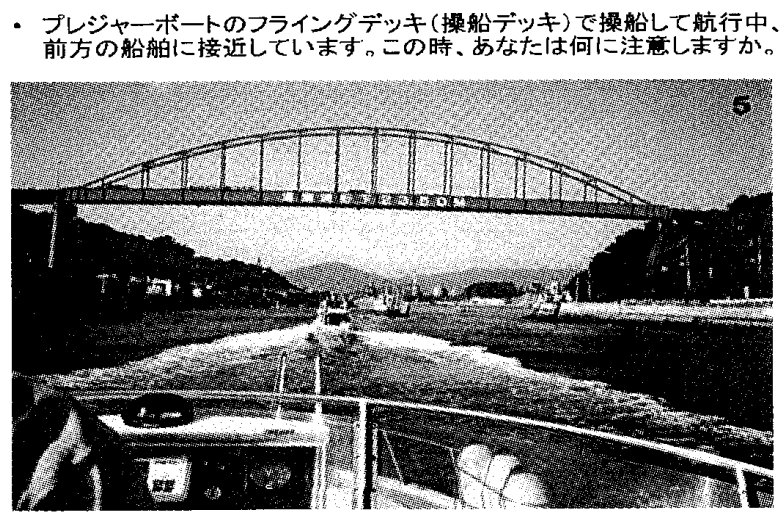

困 4 危険子知シート シートN 0.10
表 1 危険予知ポイント

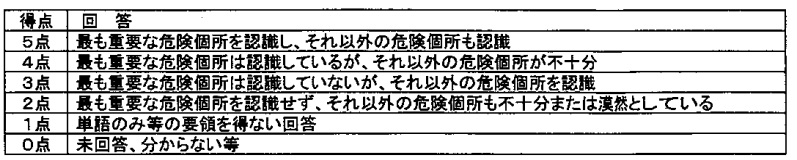

確認した。

被験者の眼球運動特性は、Free-Viewにより(1) $\mathrm{X} \cdot \mathrm{Y}$ 方向注視角度 (deg)、(2)眼球運動速度（deg／ $\mathrm{sec}) 、$ (3)注視時間 $(\mathrm{msec}) 、(4)$ 瞬目（まばたき）時間 $(\mathrm{msec}) \cdot$ 回数、(5)曈孔径 $\mathrm{X} 、 \mathrm{Y}(\mathrm{dot})$ 等の項目につ いて自動的に記録される。

提示した15枚の危険予知シートは、自動車を運転 している場面でJAFが作製したものが 5 枚、神戸商 船大学が作製したプレジャーボート版が10枚であ る。

各設問に対する被験者の回答は、実験者があらか じめ設定した危険個所に基づいて表 1 に示す 5 段階 の危険予知ポイントとして評価した。

被験者は、神戸商船大学の 1 年生 26 名(男性 21 名, 女性 5 名）、 2 年生 5 名（すべて男性）の計 31 名で、 いずれの被験者も色覚異常等の眼科的疾患はない。

\section{2 実験装置}

実験に使用した眼球運動測定装置は、(株) 竹井機 器工業製のFree-View /Ver.6.0/T.K. K.2920 である。この装置の規格を表 2 にまた刺激提示部、 処理部、眼球検出部で構成される装置の概要を図 5 に示す。

Free-Viewは、人間の眼球運動をより簡便に、そ して被験者を拘束することなく測定することを目的 として開発された非接触型の眼球運動測定装置であ る。そして、視对象をディスプレイに限定した装置

\section{表 $2 \quad$ Free-View規格}

\begin{tabular}{|c|c|}
\hline 眼球検出部 & \\
\hline 検出方法 & 眼球映像 画像処理方式 \\
\hline LED発光ピーク波長 & $850[\mathrm{~nm}]$ (近赤外) \\
\hline 眼球摄影カメラ & 白黒CCDカメラ \\
\hline 検出眼 & 片眼 \\
\hline 検出距離範囲 & $\begin{array}{l}\text { 0.5〜1.5[m] } \\
\text { (眼球の反射率の鲇いなどにより制限を生しる埥合あり) }\end{array}$ \\
\hline トラッキング速度 & $10[$ 度/秒]以上 \\
\hline トラッキング笵围 & 左右各18[度]，上 $25[$ 度]、下 $5[$ 度 $]$ \\
\hline 寸法 & 約 $400(\mathrm{~W}) \times 305(\mathrm{D}) \times 175(\mathrm{H})[\mathrm{mm}]$ \\
\hline 重量 & $7.2[\mathrm{~kg}]$ \\
\hline 電源 & $\mathrm{AC} 100[\mathrm{~V}] \pm 10[\%], 50 / 60[\mathrm{~Hz}]$ \\
\hline 消費電力 & 約 $50[w]$ \\
\hline 迌理部 & \\
\hline 検出角度算囲 & 水平垂直とも士20[度](セツテイング桑件により制限あり) \\
\hline 最大検出分解能 & O. 2[度]以上 \\
\hline 検出糟度 & $0.5[$ 度]以上 \\
\hline サンプリング時間 & $30[\mathrm{~Hz}]$ \\
\hline 測定遲延時間 & 2[フレーム]以内 \\
\hline データメモリ数 & 100000 [個] \\
\hline 咅一夕保存形式 & テキスト形式 \\
\hline 対応OS & Windows95/98 \\
\hline 刺激映像入力 & NTSC(コンボジット、S) \\
\hline 刺激映像出力 & NTSC(コンポジット、S) \\
\hline 画像婄録出力 & PナログRGB \\
\hline 電源 & AC $100[\mathrm{~V}] 10 \pm[\%], 50 / 6 \mathrm{O}[\mathrm{Hz}]$ \\
\hline 消費電力(トータル) & 約 250[W] \\
\hline
\end{tabular}




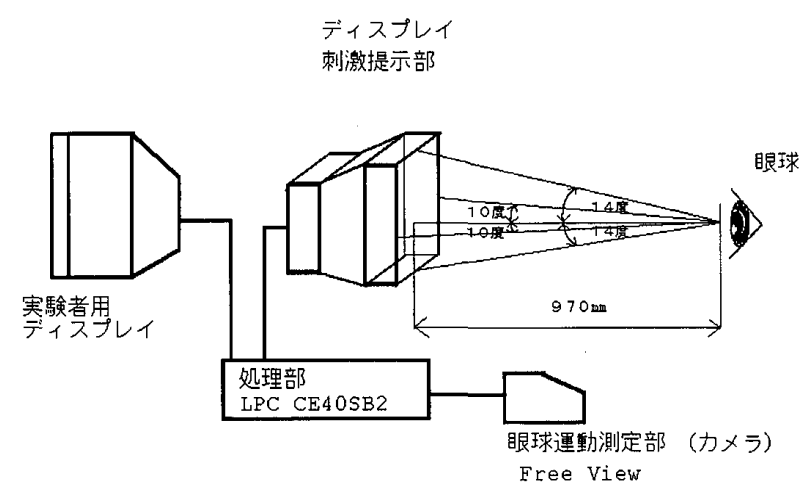

図 5 Free-View 装置概要

で、被験者の前方に配置したカメラにより撮影され た眼球映像を処理し、視線を求める方式を採用して いる。従来の強膜反射方式(3)のように検出装置(ゴー グル）を被験者に装着することが不要となり、しか も、測定準備が容易で、被験者への負担も大幅に軽 減された装置である。

\section{4. 結 果}

\section{1 解析条件}

それぞれの被験者に要する実験時間の長短がある ため、実験デー夕の解析には、計測開始時から、瞬 目及び視野角度外のデー夕を削除した 1000 データ

（サンプリング周期： $33.3 \mathrm{msec} \times 1000=33.3 \mathrm{sec}$ ) を解析対象のデータとした。また、視野角度は、装 置の検出角度範囲である \pm 20 度以内とし、被験者と ディスプレイとの距離 $(970 \mathrm{~mm})$ とディスプレイの 大きさに基づき、X方向（水平方向） \pm 14 度、Y方向 (垂直方向 $) \pm 10$ 度である。

危険子知ポイントの高い被験者と低い被験者を各 設問ごとに比較するとき、その危険予知ポイントと 眼球運動特性との関係を調べるため、危険予知ポイ ントの高・低について、それぞれ 3 名ずつの実験結 果を用いて比較した。

\section{2 平均注視位置}

眼球運動特性の注視とは、福田ら ${ }^{(4)}$ 、(5)が示し静止 画において一般的に用いられている眼球運動速度が $5 \mathrm{deg} / \mathrm{sec}$ 以下の速度成分を持つデータである。そ の注視データについて、注視角度 $(\mathrm{deg})$ のX成分と Y成分の平均値と標準偏差を算出する。平均值を中 心としてそれぞれの標準偏差で棈円近似したものを 図6.1及び図6.2に示す。

危険予知ポイントの高い被験者は、その低い被験 者と較へ、平均注視位置と危険予知シートが期待す る危険個所との距離が小さく、危険個所に対して適 切に視線が移動している状況がわかる。

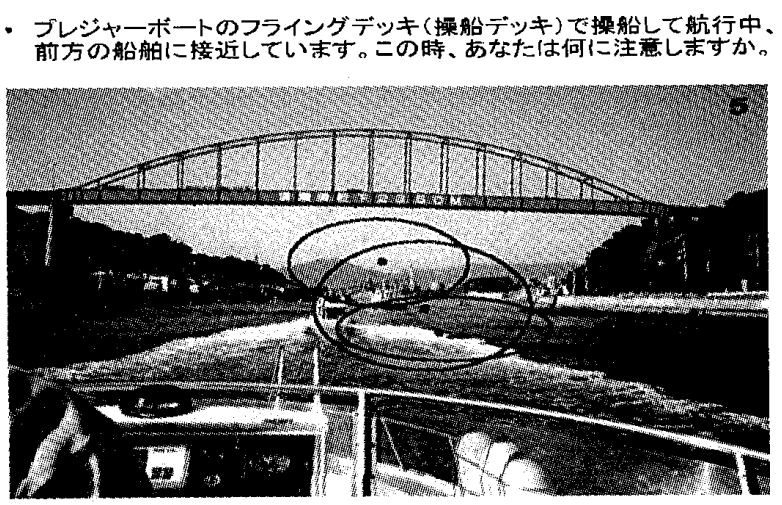

図 6-1 平均注視位置

一危険予知ポイント：高一

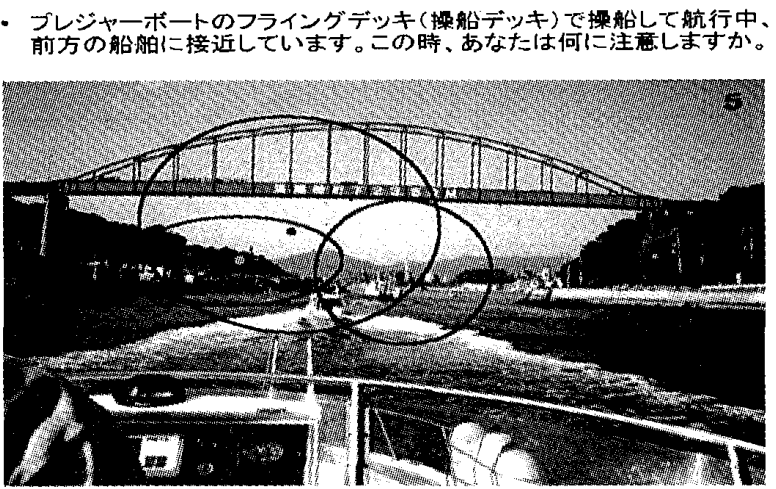

図 6-2 平均注視位置

一危険予知ポイント：低一

\section{3 注視点}

注視点は、静止画において一般的に用いられてい る眼球運動速度が $5 \mathrm{deg} / \mathrm{sec}$ 以下の速度成分（注視 成分）を持ち、さらに人間が情報を取り入れる時間 （停留時閒：一般的に150 200msec）も考慮して、 眼球運動速度が $5 \mathrm{deg} / \mathrm{sec}$ 以下の状態が $150 \mathrm{msec}$ 以 上継続した場合と定義されている。ただし、本論で の注視点は、Free-Viewのサンプリング周期が33.3 msecであるため、注視時間が $150 \mathrm{msec}$ 以上の最小值 $(167.5 \mathrm{msec}=33.3 \times 5)$ とする。

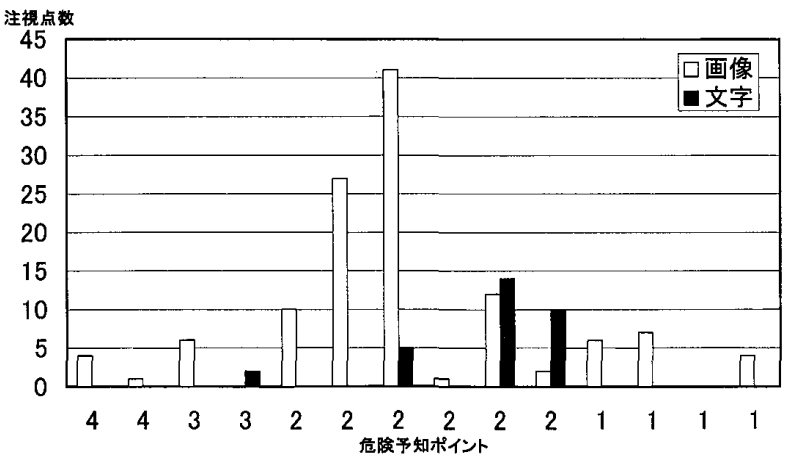

困 7 危険予知ポイントに対する注視点数 シートNo.10 
この定義に基づく注視点の数（以下 “注視点数”） について、視線が文字部分（設問部分）にあるとき と画像部分にあるときに分けて危険予知ポイントの 高い方から低い方へ並べたものを図 7 に示す。

注視点数は個人差が大きく、各設問ごとの比較に おいても特徵的な傾向は見られなかった。さらに、 注視時間についての最大値、あるいは平均值も個人 差が大きく、特徵的な傾向は見られなかった。

\section{4 眼球運動速度}

図 8 は、ある被験者が危険子知シート（№.3）を 観察中の眼球運動速度分布である。危険予知シート 中の画像部分と文字部分について、横軸に示す眼球 運動速度の区分ごとにそれぞれのデー夕数に対する 生起率（\%）を縦軸に示す。

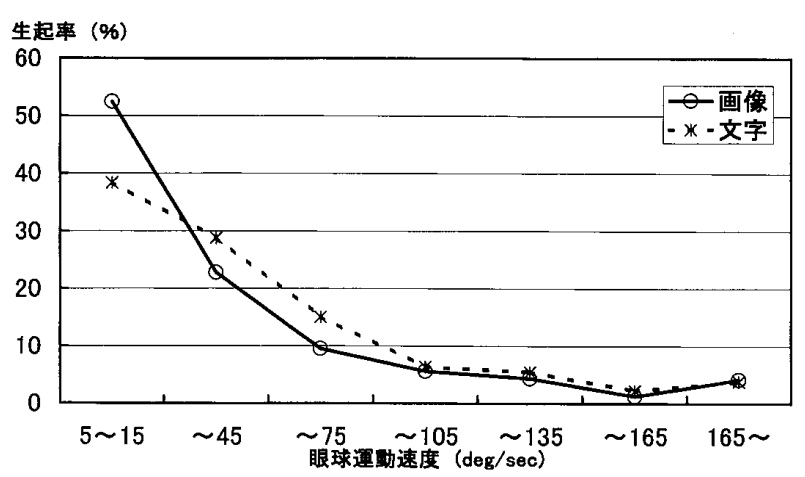

図 8 眼球運動速度の分布

危険予知シート中の文字を読む場合と画像を見る 場合を比較すると、眼球運動速度が5〜15deg／ $\mathrm{sec}$ 以下の生起率は、画像を見る場合に大きく、15〜45 deg／sec以下では文字を読む場合に大きく、その生 起率が逆転していた。この結果は全ての被験者につ いて確認され、眼球運動速度の分布の特徵的な相違 であるといえる。これは文字情報を認識する場合と 画像情報を認識する場合のそれぞれの特徵である。

JAF版の危険予知シート（シートNo.1～5）につ いて、瞬目を除く解析可能なデー夕数が 1000 データ

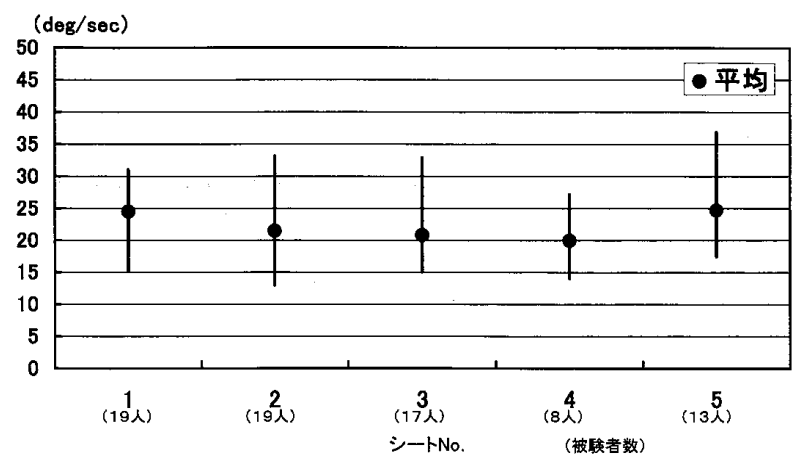

図 9 眼球運動速度の平均値
以上得られた被験者（No.1\&No.2：19名、No.3:17 名、No. 4 ：8名、No. 5 ：13名）に関する眼球運動速 度 (平均) の平均值を図 9 に示す。

眼球運動速度の平均值は、シートの相違による差 は少なく20〜25deg／secであった。

\section{5 . 考察}

(1) 平均注視位置 ${ }^{(6)}$

平均注視位置は、危険予知シートの“何を”、ある いは“どこ”を見ているかというまさしく観点の問 題、すなわち “目の付けどころ”の問題である。平 均注視位置は、眼球運動の定性的な特性を示す指標 である。

危険予知シートには、危険な状況が数点含まれて いるのが一般的である。その中から、最も危険なポ イントを視覚情報として探り出すために、眼球運動 による視線移動は休みなく継続されている。

図10は、シートNo.1・№.3・No.4の3 枚について、 危険予知ポイントの高い被験者と低い被験者それぞ れ3 名ずつの平均注視位置を比較したものである。 原点は最も重要な危険個所を表す。

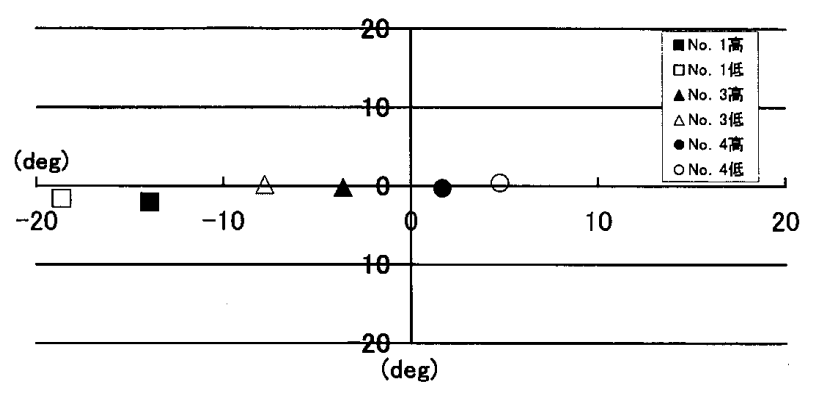

図10 平均注視位置の相違

一危険予知ポイントの高低比較一

平均注視位置の違いは、危険予知ポイントの高い 被験者と低い被験者を比較すると、前者の平均注視 位置は最も重要な危険個所に近いことがわかる。

この傾向はシートN No. 2 及びNo. 5 では見られない。 それは、シートNo.2の画像中心付近に危険個所があ ク、また、シートN No. 5 では左右に分かれて危険個所 があるためであろうと推察できる。

この結果は、危険予知シートに示された危険個所 の明示性に関連し、危険予知シートの完成度に左右 される傾向があると推察する。

(2) 注視点

注視点は、危険予知シートに示された上述の平均 注視位置を“どのように”、あるいは“どれくらい” 見ているかという注視状況の問題、すなわち “目の 
付け方”の問題である。

注視点数及び注視時間については個人差が大き く、各シートごとの比較、最大值、あるいは平均值 には特徴的な傾向は得られなかった。このことは、 静止画に示された危険個所に対する“目の付け方” は個人差が大きく、注視点数及び注視時間と危険予 知ポイントとの関係は小さいといえる。

\section{（3）眼球運動速度}

眼球運動速度は、危険予知シートを“どのように” 見ているかという視線の動き方に関する観察状況の 問題、すなわち“目の動き”の問題である。眼球運 動速度は、眼球運動の定量的な特性を示す指標であ る。

眼球運動速度の分布は、危險予知シート中の文字 を読む場合と画像を見る場合を比較すると、眼球運 動速度の区分に対して生起率が逆転するという特徵 的な相違が見られた。これは文字情報の認識を通じ て、その文字情報から得られた文脈に対する理解を 経る過程と画像情報の認識を通じて、その画像情報 から得られる状況に対する過程に違いのある、いわ ゆる情報源の性質が異なる場合の特徵であるといえ る。このことは、静止している視覚対象から限られ た情報を得ようとするときの眼球運動特性を示して いるものと推察できる。この点について、画像情報 と文字情報を同時に対比した研究事例はなかった が、福田らの研究により音符と文字という情報源の 違いによる情報処理量の相違について、眼球運動を 解析した事例がある(4)。

眼球運動速度の平均值が、シートの相違による差 は少なく20２5deg／secであるという結果は、日本 人が書籍から日本語を読む場合の眼球運動速度と類 似し(4)、静止画から視覚情報を獲得するときの眼球 運動特性を示している。

（4）危険予知ポイントと眼球運動特性

平均注視位置に着目し、危険個所と平均注視位置 との距離について各シート每の危険箇所に対する距 離等を検討し、危険予知を評価できる可能性を示す ことができた。しかし、平均注視位置に関する特徴 がすべての危険予知シートに当てはまる訳ではな い。それは危険箇所の多少や軽重、危険箇所の大小、 シートが示す状況の複雑さ等の危険予知シートに含 まれる情報の量や質というシート完成度によるもの であろう。

危険予知ポイントを眼球運動特性から検討する場 合、眼球運動速度や注視点数、注視時間という定量 的な特性から危険予知ポイントと眼球運動特性との 関係は少なかった。従って、情報を認識する段階で
は危険子知ポイントに大きな差があるとは言えな W。

危険予知ポイントの差に表れる情報認識の差は、 危険子知の位置づけから考察すると、被験者自身の 予測や判断の過程に大きく影響された結果であろう と推察する。

危険予知ポイントの高い被験者と低い被験者を比 較すると、眼球運動の動的な特性に差はなく、平均 注視位置にその相違が見られることから、両者の相 違は危険個所がわからないという目の付け所の違い といえる。

そこで、危険予知ポイントの低い被験者には、危 険個所を具体的に指摘することが危険予知ポイント を高め、ヒューマンエラーの防止につながるものと 期待できる。

（5）危険子知シートの改善

Free-Viewを利用した被験者の危険予知に対す る検討に加之、JAF版危険子知シートを用いて得ら れた眼球運動特性からプレジャーボート版危険子知 シートを検討し、その改善点を探る。

“目の付けどころ”の問題である平均注視位置の 比較から検討すると、危険予知ポイントが高い被験 者の平均注視位置は危険個所の近くにあるという傾 向を示したプレジャーボート版危険子知シートは 1 枚（No.10）だけであった。それ以外のシート（9枚） では、危険個所の特定に必要な知識、経験が不足し ているために危険個所を認識することができなかっ た場合、あるいは提示された危険個所が小さいため に特定できなかった場合があった。

このように、危険子知ポイントの違いにより平均 中止位置と危険箇所との距離差が大きかったシート と小さかったシートの比較や、実験終了後に得られ た被験者の感想等から考察した危険子知シートの完 成度を高めるための改善点は、次の 4 点である。

1）危険予知シートから得られる情報量を多くし、 船種、航行環境（港湾構造物、水深等）等の要素を 取り入れること。

2）最も重要な危険個所が明らかにわかるように、 危険個所を提示する大きさやその提示位置を工夫す ること。

3）被験者（画像における観察位置）自身の状況が 把握できるように、視点の位置や自船の進行方向が わかる要素を含めること。

4）被験者（画像における観察位置）周囲の状況が 把握できるように、自船の大小や船舶の輻輳度がわ かる要素を含めること。 


\section{6.まとめ}

船舶交通や海上労働における災害を防止するため の危険予知を導入し、その効果的な手法を提言する ために、危険予知シート (静止画) から得られる視 覚情報を認識する際の一般的な視覚特性や危険な状 況を認識する際の眼球運動特性を実験調査し、危険 予知の手法と評価に関して次のようにまとめる。

(1) 平均注視位置

○危険予知ポイントの高い被験者の平均注視位置 は、危険予知シートに示された最も重要な危険個所 に近い傾向がある。この傾向は、最も重要な危険個 所が危険予知シートにどの程度明らかに示されてい るかという危険予知シートの完成度に左右される傾 向がある。

(2) 注視点

○危険予知シートに示された危険個所に対寸る “目の付け方”には大きな個人差があり、注視点数 及び注視時間と危険予知ポイントとの関係は小さ W。

\section{（3）眼球運動速度}

○危険予知シート中の文字を読む場合と画像を見 る場合を比較した場合、その眼球運動速度の分布は、 文字と画像という情報源の違いにより異なる。

○眼球運動速度の平均值は、危険予知シートの相 違による差は少なく20２5deg／secである。

（4）危険予知ポイントと眼球運動特性

○危険予知ポイントの低い被験者に対して危険個 所を具体的に指摘することは、危険子知ポイントを 高め、ヒューマンエラーの防止につながる可能性が 大きい。

\section{7.おわりに}

ヒューマンエラーを防止するために、本論で紹介 したようなシートを用いた危険予知という手法があ る。危険予知シートを提示しながら眼球運動を解析 し、効果的な危険予知を行うための手法を検討した。 今回の実験は、危険予知シートの視覚情報から危険 個所を抽出する一般的な眼球運動特性を調べるため に、知識・経験の少ない学生が被験者であった。

今後は、Free-Viewによる眼球運動特性の解析を 進めながら、経験・知識の多少が危険予知に及ぼす 影響や、音声情報を含めた情報提示方法の違いによ る比較・検討を通じて、危険予知シートの改善と ヒューマンエラー防止のための提言に取り組みた い。

\section{参 考 文 献}

（1）長町三生：安全管理の人間工学, 海文堂, p. 8 $\sim 10,1995$.

（2）企業開発センター交通問題研究室, 交通安全学, 大阪交通科学研究会, pp.242 254，2000.

（3）福田忠彦・渡辺利夫：ヒューマンエスケープ-視 覚の世界を探る-，日科技連，p.102・p.144・p. 126 137, 1996.

（4）福田忠彦：生体情報システム論, 産業図書, pp. 34, 1995.

（5）山田光穂・福田忠彦：画像に扔ける注視点の定 義と画像分析への応用，電子情報通信学会論文 誌, J69-D, pp.1335〜1342， 1986.

（6）古荘雅生・甲斐繁利・橋本 進：視線の動きか ら見た高速船（ジェットフォイル）操縦者の見 張りについて，日本航海学会論文集第85号，pp. $51 \sim 62,1991$.

\section{質 疑 応，答}

嶋田博行 (神戸商船大学)：

（1）危険子知シートは海上版と陸上版を混ぜて提 示なさったのでしょうか。

（2）まとめで得られた「眼球運動速度における文 字と画像との情報源の違い」に関するデータは、 海上版と陸上版の両方を含んだデータでしょう か。

（3）危険予知シートの改善は、どのデー夕に基づ いて、どのように改善すべきと考えられたので しょうか。改善の根拠となるデー夕はどれなので しょうか。

\section{平井貴裕 :}

（1）心理学的な実験では、実験手順やシート（刺 激）の提示方法の違いが実験結果に大きく影響す ることは周知の事実であります。陸上版 (JAF版) 危険予知シートは、数多くの陸上交通場面から収 集されたシートであり、危険予知を行うための適 切なシート情報が含まれています。一方、海上版 シートは、カーフェリーでの作業場面を含めても、 その撮影枚数が約 1,000 枚程度と少なく、今回使用 した危険予知シートは、その中から適切なシート 情報が比較的多く含まれているものを使用しまし た。そこで、陸上版シートと海上版シートは、シー トの完成度が異なるために、まず陸上版シートを シート番号順に提示し、その後海上版シートを シート番号順に提示しました。交互作用 (Interaction）の影響をできる限り小さくするために、各 シートの提示順序はランダムとすべきでしたが、 
この実験では、陸上版、海上版それぞれのシート 番号順に被験者に提示しました。

（2）海上版危険予知シートの回答では、被験者間 の回答に大きな違いが見られず、また解析に必要 なデー夕数（1000個）に満たない場合が多かった ため、陸上版危険予知シートのデー夕を使用しま した。それは、被験者の海上経験について、1 年 生は神戸商船大学練習船、 2 年生は神戸商船大学 練習船と航海訓練所練習船による乗船実習のみで あったこと、そして、シートに含まれる危険予知 のための情報量が少なく、しかも危険個所が分散 していたこと等によりシートの完成度が低いと判 断したためです。

（3）シートの改善点は、危険個所と解析結果から 得られた平均注視位置との関係、及び被験者に対 する実験終了後に行った被験者に対するヒアリン グ調查、さらに学部生時代の特別研究で行った
シート作成のための写真撮影作業から得られた反 省事項に基づき総合的に考察したものです。

山田孝三郎（日立造船）：海上における危険の状況は 船の種類、水路、海象など多種多様な要素が複合 していると考えますが、海上版危険予知シート 10 枚を代表的に選択する時の考え方をご教示下さ い。

平井貴裕：今回の海上版危険予知シートは、実際の プレジャーボートの運航中に遭遇する様々な海上 場面を約1000枚撮影したものです。その中から危 険と思われる要素が比較的多く含まれている写真 をピックアップしました。今回の解析に使用した 危険予知シート（海上版）は意図的にどのような 場面を撮影しようとしたものではないため、危険 予知シートの改善点を提案しました。シートの改 善点を考慮した危険予知シートの撰択が必要で す。 